\title{
Mouse models to study dengue virus immunology and pathogenesis
}

\section{Raphaël M. Zellweger and Sujan Shresta*}

Division of Vaccine Discovery, La Jolla Institute for Allergy and Immunology, La Jolla, CA, USA

\section{Edited by:}

Scott B. Halstead, International

Vaccine Institute, South Korea

\section{Reviewed by:}

Lishan Su, University of North

Carolina at Chapel Hill, USA

Alexis DeHaven Dunkle, Lawrence

Livermore National Laboratory, USA

*Correspondence:

Sujan Shresta, Division of Vaccine

Discovery, La Jolla Institute for Allergy and Immunology, 9420 Athena Circle,

La Jolla, CA 92037, USA

e-mail: sujan@lji.org

\begin{abstract}
The development of a compelling murine model of dengue virus (DENV) infection has been challenging, because DENV clinical isolates do not readily replicate or cause pathology in immunocompetent mice. However, research using immunocompromised mice and/or mouse-adapted viruses allows investigation of questions that may be impossible to address in human studies. In this review, we discuss the potential strengths and limitations of existing mouse models of dengue disease. Human studies are descriptive by nature; moreover, the strain, time, and sequence of infection are often unknown. In contrast, in mice, the conditions of infection are well defined and a large number of experimental parameters can be varied at will. Therefore, mouse models offer an opportunity to experimentally test hypotheses that are based on epidemiological observations. In particular, gain-of-function or loss-of-function models can be established to assess how different components of the immune system (either alone or in combination) contribute to protection or pathogenesis during secondary infections or after vaccination. In addition, mouse models have been used for pre-clinical testing of anti-viral drugs or for vaccine development studies. Conclusions based on mouse experiments must be extrapolated to DENV-infection in humans with caution due to the inherent limitations of animal models. However, research in mouse models is a useful complement to in vitro and epidemiological data, and may delineate new areas that deserve attention during future human studies.
\end{abstract}

Keywords: dengue, vaccines, mouse models, antibody-dependent enhancement, adaptive immunity

\section{INTRODUCTION}

Dengue virus (DENV) is the etiologic agent of the self-limited febrile illness dengue fever (DF), as well as the potentially lethal severe dengue disease (previously referred to as dengue hemorrhagic fever and dengue shock syndrome, DHF/DSS). Infection with DENV is often asymptomatic in humans (1). Symptomatic infections are characterized by: fever, retro-orbital headache, muscle, joint and bone pain, nausea, vomiting, abdominal pain, mucosal bleeding, and low platelet count. In the most severe form of the disease, severe bleeding, organ dysfunction, vascular permeability, and shock can occur $(2,3)$.

The four serotypes of DENV are the most prevalent mosquitoborne viruses that affect humans (4). In tropical and sub-tropical regions, it is estimated that 2.5-3.6 billion people are at risk of infection in over 100 countries $(2,5,6)$. The development of an adequate mouse model for dengue infection has been challenging, mainly because DENV clinical isolates fail to replicate or cause pathology in wildtype (WT) mice. A reliable mouse model of DENV-infection would be an excellent complement to in vitro data and epidemiological studies, allowing for testing of hypotheses based on human observations, and providing insights into mechanisms of pathogenesis and immunity to DENV.

\section{EXISTING ANIMAL MODELS OF DENV-INFECTION}

Developing a relevant animal model for DENV-infection has been a long-standing challenge. The lack of an adequate animal model for DENV-infection is often mentioned as a major hurdle to a better understanding of DENV pathogenesis in humans. Numerous efforts to overcome this difficulty have resulted in many animal models. Though not perfect, these models have been useful to complement in vitro and human studies.

\section{NON-HUMAN PRIMATE MODELS OF DENV-INFECTION}

Non-human primate (NHP) models of DENV-infection exist, and have been recently reviewed (7). Viremia and humoral immune responses can be detected in NHP after DENV-infection, but usually no clinical signs of disease are observed (8-12). One study reported hemorrhage after infection with DENV (13). Due to the absence of signs of disease, it is difficult to study DENV-induced pathology in NHP, but NHP can be used for testing immunogenicity, safety, and/or protective efficacy of dengue vaccine candidates by measuring induction of anti-DENV antibodies and magnitude and duration of viremia after vaccination or challenge (14-23). Thus, in the context of vaccination, the antibody and viremia data from NHP models have been used to provide correlates of protection from infection but not from pathogenesis.

\section{WILDTYPE MOUSE MODELS OF DENV-INFECTION}

In many WT mouse models, intravenous (i.v.) or intraperitoneal (i.p.) DENV-infection results in neurological abnormalities but not the usual clinical signs observed in humans (24-27). Involvement of the central nervous system during DENV-infection in humans has generally been considered unusual $(28,29)$, although recent studies [reviewed in Ref. (3)] suggest that it is a frequent 
complication (30-33). Central nervous system involvement is now considered criteria for severe dengue in the World Health Organization (WHO) case classification $(2,3)$. Intracranial (i.c.) inoculation of DENV in WT mice also results in neurological symptoms and death (34-37), however this inoculation route does not accurately mimic natural infection, which occurs when DENV-infected mosquitoes feed on a human. In C57BL/ 6 mice, a high inoculum of the non-mouse-adapted DENV2 strain 16681 resulted in systemic hemorrhage after intradermal (i.d.) infection (38) and abnormal liver function after i.v. infection (39). It is still a matter of debate which experimental route of infection (i.d. or i.v.) is the most relevant. While neither perfectly mimics the bite of an infected mosquito, i.d. and i.v. routes of infection are often used in laboratories when mosquito-mediated infection may not be possible. In another immunocompetent mouse model, presence of DENV was transiently detected in the serum of ICR, ddY, and Balb/c mice after i.p. injection of DENV-infected K562 cells (40). Collectively, the absence of overt signs of disease in WT mice after DENV-infection has been a major drawback of WT models to date.

\section{MICE DEFICIENT IN IFN $-\alpha / \beta$ AND $-\gamma$ RECEPTORS (AG129) TO STUDY DENV-INFECTION}

In humans, DENV inhibits IFN signaling to establish infection, whereas DENV is unable to do so in mouse cells (41-43). Specifically, DENV NS5 can bind to and degrade human STAT2 (44), but not mouse STAT2 (41) and the DENV NS2B3 proteolytic complex can degrade human STING but not its mouse homologue $(42,43)$. The extreme sensitivity of DENV to type I IFN is highlighted by a recent study demonstrating effective viral clearance in mice deficient in both IRF-3 and IRF-7, which mount a weak and delayed type I IFN response during DENV-infection (45). Another study has demonstrated in mice that type II IFN efficiently limits DENV spread (46). Taken together, the high sensitivity of DENV to IFN and the fact that DENV inhibits IFN signaling in humans but not in mice could possibly explain why DENV clinical isolates do not easily replicate in WT mice.

In contrast to WT mice, mice deficient in IFN- $\alpha / \beta$ and $-\gamma$ receptors on 129/Sv genetic background (AG129) support robust levels of DENV replication (47), and have thus widely been used as a mouse model of DENV-infection. Intraperitoneal infection with a mouse-adapted DENV-strain was lethal in AG129 mice, regardless of their age (47). While i.p. may not accurately mimic the natural route of infection, similar results were obtained in subsequent studies using i.v. inoculation. In those studies, i.v. infection of AG129 mice with a mouse-adapted DENV serotype 2 strain (DENV2) resulted in non-paralytic lethal dengue disease with signs of vascular permeability and TNF release $(48,49)$. This model has been used to demonstrate that passive transfer of subprotective levels of anti-DENV antibodies before infection can turn a mild illness into a lethal disease recapitulating many signs of severe dengue disease, including viremia, cytokine storm, low platelet counts, elevated hematocrit, increased vascular permeability, and intestinal hemorrhage (50,51). AG129 mice were also used to demonstrate the therapeutic efficacy of anti-DENV antibodies lacking the ability to bind the $F c \gamma$ receptor (52). Recently, i.p. infection with a non-mouse-adapted DENV2 strain (D2Y98P) was shown to cause cytokine storm, organ damage, and vascular leakage in AG129 mice $(53,54)$. If infected with lower doses of DENV2, AG129 mice do not develop severe dengue-like lethal disease, but instead neurological symptoms appear and result in paralysis later on $(46,51)$.

\section{MICE DEFICIENT IN IFN- $\alpha / \beta$ RECEPTORS (IFNAR ${ }^{-/-}$) TO STUDY DENV-INFECTION}

In contrast to AG129 mice lacking both IFN- $\alpha / \beta$ and $-\gamma$ receptors, mice lacking IFN- $\alpha / \beta$ receptor only (IFNAR ${ }^{-/-}$) do not develop paralysis after i.v. infection with DENV2 (mouse-adapted) because IFN- $\gamma$ and $\mathrm{CD}^{+}{ }^{+} \mathrm{T}$ cells prevent DENV-induced pathology in the central nervous system $(46,55)$. Instead of paralysis, these mice develop a severe dengue-like disease when infected with sufficiently high DENV2 challenge doses (46) or in the presence of sub-neutralizing (and enhancing) anti-DENV antibodies (51). IFNAR $^{-1-}$ mice have also been used to demonstrate that both $\mathrm{CD}^{+}$and $\mathrm{CD}^{+}{ }^{+} \mathrm{T}$ cells play a protective role in the context of primary DENV2 infection (mouse-adapted strain, i.v. infection) and peptide vaccination $(56,57)$.

Recently, IFNAR ${ }^{-1-}$ mice have been crossed with transgenic mice expressing human HLA molecules in order study antiDENV-T cell responses restricted by human HLA (58). Observations made in those mice confirmed the role of NS3 and NS5 as major targets of the T cell response in humans (59), identified several novel human DENV-T cell epitopes, and highlighted the dominance of HLA-B*0702 restricted responses (58).

Sustained DENV replication and severe dengue disease manifestations in IFNAR ${ }^{-1-}$ and AG129 mice are a clear advantage to study DENV pathogenesis in vivo, but the absence of intact IFN signaling is a limitation that must be taken into account when interpreting data. In particular, immune responses to DENV are altered in IFNAR ${ }^{-1-}$ and AG129 mice compared to WT mice, as IFN is a key component of the immune system. Therefore, findings made in IFNAR $^{-1-}$ and AG129 mice may not accurately reflect what would happen in a fully immunocompetent environment. It would be desirable to validate the findings made in IFN-deficient mice with another model, or with data from epidemiological studies.

\section{“HUMANIZED” MICE TO STUDY DENV-INFECTION}

Another approach aimed at modeling DENV-infection in mice has been to graft human tumor cells into severe combined immunodeficient (SCID) mice lacking T and B cells. As SCID mice are unable to reject the graft, the transplanted human tumor cells provide a permissive environment for DENV replication. DENV replication was observed after transplantation of human hepatocarcinoma hepG2 (60) or human leukemia K562 cells (61). Viremia and some signs of disease (mild hemorrhage, thrombocytopenia, and elevated TNF levels) were detected in one study (60), but ultimately mice succumbed to paralysis. As DENV replication is restricted to the transplanted transformed human cells, extrapolation of results to human disease may be difficult.

Human $\mathrm{CD}^{+} 4^{+}$hematopoietic stem cells have also been used to reconstitute irradiated NOD/SCID (62) or NOD/SCID/IL-2R $\gamma$ null (63-65) mice. Graft-rejection is minimized in NOD/SCID/IL$2 \mathrm{R} \gamma$-null mice due to dramatic defects in both adaptive and innate immune systems. Therefore in irradiated NOD/SCID/IL-2R $\gamma$-null mice, the efficiency of reconstitution by human $\mathrm{CD}^{+} 4^{+}$cells is 
maximized. In the resulting "humanized" chimeras (hu-NSG), human cells of the adaptive and innate immune systems develop with various degrees of reconstitution depending on the animal, the organ, and the laboratory $(62,66,67)$. Fever, rash, viremia, erythema, and thrombocytopenia have been observed in humanized mice after DENV-infection $(62,63,65)$, and human cells were infected in the bone marrow, spleen, and blood (62). Production of anti-DENV IgM and cytokines was also observed in those mice $(64,65,68)$. Similar to NOD/SCID/IL-2R $\gamma$-null mice, immunodeficient RAG2 ${ }^{-1-} / \gamma \mathrm{c}^{-1-}$ mice can also be reconstituted with human hematopoietic stem cells (67). DENV-infection of humanized $\mathrm{RAG}^{-1-} / \mathrm{\gamma c}^{-1-}$ resulted in viremia, fever, and production of human IgM and IgG (69). Recently, NOD/SCID/IL-2R $\gamma$-null mice have been co-transplanted with cord blood hematopoietic stem cells and human fetal thymus and liver tissues, which resulted in higher immune responses to DENV-infection (neutralizing IgM and IFN- $\gamma$ production) (70). In another study, NOD/SCID mice were grafted with human fetal liver and thymus prior to reconstitution with human $\mathrm{CD}^{+} 4^{+}$hematopoietic stem cells (71). In those mice, infection with DENV resulted in viremia, infection of human leukocytes, cytokine production, and production of DENV-specific IgM. Also, viral RNA levels were reduced by administration of an adenosine nucleoside inhibitor of DENV, either simultaneously or after infection (71). Based on those results, the authors suggest that "humanized" mice could be used to test the efficacy of anti-viral drugs or, potentially, the protective efficacy of vaccine candidates.

While using mice reconstituted with human cells offers the possibility to study DENV-infection of human cells in vivo, this approach is labor-intensive and important variations are observed in the degree of reconstitution of the recipients $(62,66,67)$. In addition, cellular and molecular interactions between the grafted human cells and the murine environment may be absent or altered compared to the interactions that would take place in a natural environment. Therefore, transferred human cells may not function in the murine environment as they would in their natural (human) environment. Overall, few signs of severe dengue disease are observed in "humanized" mice, and some aspects of both adaptive and innate responses are not fully functional (67). Cellular immune responses are usually observed after viral infection, but isotype class-switch does not readily occur in these mice (67).

Various mouse models of DENV-infection exist, each one with specific strengths and limitations. While improvement of the current models would be desirable, these models have been used to test anti-viral drugs and vaccine candidates, or to provide insights into mechanisms of DENV pathogenesis. As pathogenesis and immune responses after DENV-infection probably differ between mice and humans, extrapolation of findings made in mice to DENV-infection in human should be done with caution. This limitation has to be kept in mind when reviewing any data generated in animal models.

\section{USE OF MOUSE MODELS FOR DRUG AND VACCINE DEVELOPMENT}

Efforts to develop efficient therapeutics and vaccines against DENV are still ongoing. Studies using mouse models of DENVinfection could be used for drug development, or provide valuable information on safety, immunogenicity, and efficacy of vaccine candidates before they reach the clinical testing stage.

\section{ANTI-VIRAL TESTING IN MOUSE MODELS OF DENV-INFECTION}

Several anti-viral drug candidates have been tested in WT mice after i.c. infection, or in AG129 mice. The alpha-glucosidase inhibitor castanospermine (a natural alkaloid) can inhibit DENVinfection by preventing correct folding of viral structural proteins (72) and prevent mortality after i.c. DENV challenge in WT mice (73). Contrary to WT mice, in which DENV is lethal only after i.c. challenge, AG129 mice support DENV replication and show signs of severe dengue disease following i.p. or i.v. infection with certain DENV-strains (48-54). Therefore, this model has been widely used to test the ability of anti-viral drugs to limit DENV replication and dissemination, and/or prevent signs of disease. Mortality, viral load, and signs of disease can all be used as readouts for the drug efficacy. Iminosugars have anti-viral properties, as they prevent correct protein folding by inhibiting glycoprotein processing enzymes $\alpha$-glucosidases I and II (74). In AG129 mice, various iminosugars have been shown to reduce viremia, prevent cytokine storm, and/or limit mortality after DENV-infection (75-80). One study showed that co-administration of ribavirin enhanced the anti-viral activity of the iminosugar (76). Furthermore, an adenosine nucleoside could limit viremia and reduce mortality in DENV-infected AG129 mice, presumably by blocking viral RNA synthesis $(81,82)$. Another compound, which inhibited RNA translation, reduced peak viremia in AG129 mice (83). Other DENV inhibitors targeting the NS3 helicase (84) or the capsid protein (85) have also successfully reduced viremia and organ viral titers in AG129 mice. In recent years, AG129 mice have increasingly become the standard mouse model for in vivo testing of anti-viral candidates that impact viral replication through type I and II IFN-independent pathways.

\section{MOUSE MODELS TO TEST SAFETY OF DENV-VACCINE CANDIDATES}

A successful vaccine should induce protective immunity in the host without causing pathology. This is particularly true for liveattenuated vaccines, which are often derived from more virulent parental strains. Mouse models in which DENV can replicate and cause disease can be used to assess the safety of vaccine candidates. Duration and magnitude of viremia, morbidity, and (potentially) mortality after vaccination can be used as readouts to assess the degree of attenuation of vaccine candidates compared to the parental, non-attenuated strain. The degree of attenuation of live DENV-vaccine candidates has been tested in suckling mouse brains (86) and in SCID mice transplanted with human liver cells $(18,87,88)$. The WHO has suggested that the AG129 mouse model may be adequate to test the safety of live-attenuated DENV-vaccine candidates, as the potential to cause disease (compared to the parental, non-attenuated strain) can be evaluated in those mice (89). However, the authors point out the difficulty of interpreting the results, as AG129 mice lack both type I and II IFN receptors. In addition, the risk of inducing antibody-dependent enhancement after vaccination can readily be assessed in AG129 mice, as viral titers and morbidity have been shown to increase when subneutralizing amounts of anti-DENV antibodies are administered prior to infection $(50-52,90)$. 


\section{MOUSE MODELS TO TEST IMMUNOGENICITY AND EFFICACY OF DENV-VACCINE CANDIDATES}

Immunogenicity and efficacy of DENV-vaccine candidates have also been tested in both AG129 and WT mice. The effect of immunization on subsequent challenge can easily be observed in AG129 mice, as the appropriate DENV-strain will replicate to measurable levels and cause pathology in those mice. A protective vaccine should reduce viral titers and pathology, as well as increase mean survival time after lethal challenge. Live-attenuated monovalent and tetravalent vaccine candidates induced neutralizing antibodies in AG129 mice, and protected from lethal DENV challenge $(23,91$, 92). One study reported induction of DENV-specific $\mathrm{CD} 8^{+} \mathrm{T}$ cells after vaccination of IFNAR $^{-1-}$ mice (23). Recently, immunization with a non-propagating alphavirus replicon particle expressing a truncated version of the DENV envelope protein induced both cellular and humoral immunity, and was able to protect AG129 mice form lethal i.v. DENV challenge (90). The limitation of using AG129 mice is that vaccine-induced responses may be altered relative to immunocompetent mice or humans, as both type I and II IFN may regulate vaccine-induced immune responses.

Immune responses after vaccination with non-replicating DENV-vaccine candidates have also been investigated in WT mice, and neutralizing antibody responses were elicited after immunization with subunit vaccines containing portions of the DENV envelope protein $(20,93,94)$ or after DNA priming and protein boosting with various combination of envelope and non-structural proteins $(95,96)$. Many studies used i.c. lethal DENV challenge to test the protective efficacy of DENV-vaccine candidates in WT mice $(20,34,35,37,97-99)$. In those studies, the readout for protection was reduction of morbidity and/or increased survival after i.c. lethal challenge.

In general, testing the efficacy of DENV-vaccination in WT mice is difficult, as DENV challenge will not result in measurable viral titers or pathology in WT mice, with the exception of viral replication in the central nervous system after i.c. challenge (as mentioned above). One way to circumvent this problem is to use an adoptive transfer system: since many vaccines are immunogenic in WT mice, WT animals can be vaccinated and, subsequently, T cells, B cells, or serum can be transferred (alone or in combination) into naïve AG129 recipients prior to challenge. The protective or potentially enhancing effect of immune T cells, B cells, or serum can be assessed by monitoring changes in viral load or pathology in the AG129 recipient, where DENV readily replicates and causes disease. Thus, in this adoptive transfer system, the AG129 mice serve as a highly stringent challenge assay. This approach has been recently used to assess the relative contribution of $\mathrm{T}$ cells and antibodies after vaccination, revealing that not only antibodies, but also $\mathrm{T}$ cells could efficiently contribute to protection after vaccination (90).

\section{MOUSE STUDIES TO COMPLEMENT HUMAN STUDIES}

In vitro experiments cannot fully reflect the complexity of the whole organism, and human studies are descriptive by nature. In human studies, key parameters such as viral strain, dose, sequence of infection, and/or interval between infections are often unclear or cannot be easily manipulated. Therefore, research in mouse models is an ideal complement as it uses whole organisms, and allows for variation of many experimental parameters. Care must be taken while extrapolating conclusions based on experiments carried out in mice to dengue disease in humans, as there is some artificial component in all the models described so far.

\section{MOUSE MODELS TO CONFIRM OBSERVATIONS MADE IN HUMAN STUDIES}

Research in mouse models can be useful to verify hypotheses that have been based on epidemiological observations, or to gain insights into the mechanistic aspects of phenomena that have been observed in humans. For example, the hypothesis that antibody from a previous infection with a heterotypic virus (or acquired from an immune mother) can increase severity of disease upon re-infection (antibody-dependent enhancement, $\mathrm{ADE}$ ) has been postulated a long time ago $(100,101)$. Increased infection of target cells in the presence of sub-neutralizing amounts of antibody is readily observed in vitro (102-106). In monkeys, viremia increases after transfer of antibodies, but no signs of disease are observed (107, 108). Recently, the AG129 mouse model was used to demonstrate that passive transfer of sub-neutralizing amounts of anti-DENV antibodies could turn a mild illness into a lethal disease upon DENV-infection (50, 51). The antibody-induced severe dengue disease displayed many signs observed during severe dengue disease in humans: elevated viral RNA titers in multiple organs, cytokine storm, low platelet counts, elevated hematocrit, increased vascular permeability, intestinal hemorrhage, and ultimately death. Those studies also formally confirmed the involvement of the $\mathrm{Fc} \gamma$-receptor during $\mathrm{ADE}$ in vivo, and a subsequent study demonstrated the therapeutic potential of anti-DENV antibodies that no longer bind to the Fc- $\gamma$ receptor (52).

Another example is the association between high viremia and disease severity. In humans, viremia is higher and persists longer during severe dengue compared to DF (109-113). This has also been observed in mice, where disease severity has been shown to correlate with higher viremia. Mouse models have been used to explore various experimental scenarios in which viral or host factors influence virus levels and, consequently, severity of disease. In the single-deficient IFNAR ${ }^{-1-}$ mice, severity of disease correlated with the amount of virus inoculated i.v. (46). The same study showed that, at equal viral doses, the presence of intact IFN- $\gamma$ signaling reduced systemic viral spread and severity of disease. Other mouse model studies examining mechanisms of anti-viral innate immunity revealed an essential role for MAVS (55) and IRF-3/7 (45) in the initial induction of type I IFN response and control of viral replication, and for STAT1 and STAT2 in the late induction of type I IFN response and control of viral replication (114). In various studies using IFN- $\alpha / \beta$ and $-\gamma$ receptor deficient mice, the presence of sub-neutralizing levels of antibodies increased viremia and resulted in severe dengue-like disease (50-52). CD8-depletion before infection resulted in increased viral loads in another murine study (56). Many studies have also shown that virulence factors influence the outcome of the infection. One study showed that two mutations in the envelope protein of DENV were sufficient to delay virus clearance from serum, increase systemic viral loads, and induce severe dengue disease in mice (49). Similarly, a single amino acid change in the non-structural protein NS4B of a non-virulent DENV-strain caused increased RNA synthesis, increased viremia, 
and decreased survival time in AG129 mice (54). Therefore, while the observation that higher viremia correlates with disease severity has been widely made in humans, studies in mice have confirmed and extended those observations by demonstrating how particular host- and virus-associated factors impact viremia and disease severity; those factors include specific elements of innate and adaptive immune responses, presence of sub-neutralizing antibodies, size of the initial virus inoculum, and virulence of the infecting viral strain.

\section{MOUSE MODELS TO EXPLORE THE ROLE OF DIFFERENT COMPONENTS OF THE IMMUNE SYSTEM}

Human studies have suggested that the immune system can be involved in both protection and immunopathology during DENVinfection. For example, studies have shown that passively transferred anti-DENV maternal antibodies can initially protect infants against disease (115-118), but later on, as titers decrease, subprotective levels of antibody favor the development of severe disease $(115,116,118)$. T cells have also been suspected to increase disease severity: cross-reactive $\mathrm{T}$ cells raised during a primary infection have been suggested to dominate the response during a secondary, heterotypic infection, resulting in delayed viral clearance (119), altered cytokine production profile (120), or excessive cytokine release (121). However, another study showed that while cross-reactive $\mathrm{T}$ cells did dominate the response during secondary heterotypic infections, they did not show any sign of impairment (122). On the contrary, results of this study supported an HLA-linked protective role for $\mathrm{CD}^{+} \mathrm{T}$ cells.

Based on these observations, it is clear that a better understanding of the relative contribution of the cellular and the humoral arms of the immune system to protection and/or immunopathogenesis during DENV-infection is needed. Tractable, genetically manipulable mouse models enable the investigation of the role of different components of the immune system during DENVinfection, re-infection, or after vaccination. Passive transfer of serum, adoptive transfer of various $\mathrm{T}$ cell subsets, or depletion experiments should allow for a better understanding of the protective or potentially pathogenic role of the different components of the immune system, either alone or in combination. Passive transfer of anti-DENV antibodies can protect mice from intracerebral lethal challenge (123) or increase mean survival time after i.v. challenge (51). However, sub-neutralizing levels of antibodies can also increase the level of infection and/or the severity of disease in mice $(50,51)$. One study showed that the same neutralizing antibody could protect or enhance infection, depending on the amount transferred prior to infection (51). This is an in vivo confirmation of the observation made in vitro that even antibodies that are neutralizing can enhance infection when used at sub-neutralizing concentrations (103). A protective role for T cells during DENV primary infection was established in mice by showing that CD8depletion prior to infection increased viral load in various organs upon infection (56). Similarly, vaccination with CD8-epitopes (56) or CD4-epitopes (57) reduced viral load upon DENV-infection, showing that priming cellular responses before challenge was beneficial for the host. Passive transfer of homotypic or heterotypic serum or adoptive transfer of homotypic or heterotypic splenocytes before DENV challenge reduced viral load in various organs
(124). Similarly, a protective role for both cross-reactive $\mathrm{T}$ cells and B cells was shown in AG129 mice (125). Recently, the relative contribution of the humoral and the cellular arms of the immune system were assessed in mice after vaccination with a protective DENV-vaccine candidate (90). After vaccination, short-term protection was mediated by $\mathrm{CD} 8^{+} \mathrm{T}$ cells. Later on, $\mathrm{CD} 8^{+} \mathrm{T}$ cells were or were not required for protection, depending on the immunization schedule. All those studies explored the role of various components of the immune system in isolation from the other ones, which would be difficult in human studies.

Despite sustained vaccine development efforts, there is still no clinically approved vaccine against DENV (126-133). In terms of dengue vaccine development efforts to date, measuring neutralizing antibodies by plaque reduction neutralization test (PRNT) may not accurately predict the protective efficacy of a vaccine against DENV (133-135). Therefore, a better understanding of the relative contribution of the different components of the immune system to protection and/or pathogenesis is crucial to develop better correlates of protection as well as a safe and effective DENV vaccine.

\section{MOUSE MODELS TO SUGGEST AREAS OF INTEREST FOR FUTURE HUMAN STUDIES}

While research in mouse models has confirmed some of the hypotheses based on human studies, some of the findings made using mouse models need validation with human data. In this respect, the value of the mouse model is to point out possible areas of importance for future human studies. For example, elevated liver DENV titers and infection of liver sinusoidal endothelial cells (LSECs) were observed during antibody-induced severe dengue disease in mice (51). In humans, liver pathology is often observed after DENV-infection, and the degree of dysfunction may correlate with disease severity (136-140). In addition, DENV RNA or antigen has been found in the liver of patients who succumbed to DHF/DSS (141-143). Recently, a case of DENV transmission following a liver transplant has been reported (144). However, the cellular localization of DENV replication in the liver is still controversial, and possibly deserves more attention in future human studies.

Similarly, a protective role for T cells during DENV-infection has been widely shown in mice $(56,57,90)$, but human studies have only recently started to explore more in depth the protective role of T cells during DENV-infection (122). Studies in mice could suggest which $\mathrm{T}$ cell subsets are required to limit viral replication, and which T cell-mediated mechanisms protect against dengue pathogenesis during both primary and secondary infections, as well as explore further the role of sero-specific and cross-reactive T cells in protection and/or pathogenesis. IFNAR ${ }^{-1-}$ mice crossed to transgenic mice expressing human HLA molecules will also be valuable to explore anti-DENV-T cell responses restricted to human HLA. Subsequently, human studies will be necessary to verify if the findings made in mice apply to DENV-infection in humans.

\section{CONCLUSION}

While the perfect mouse model of DENV-infection has yet to be established, existing murine models of DENV-infection have, within their own limitations, been invaluable tools to complement 
and/or expand observations made in vitro or in epidemiological studies. Each model has strengths and weaknesses that must be taken into consideration when assessing data. Therefore, the choice of the best-suited model to answer a particular question is of critical importance. Mouse models have been useful to test the safety and efficacy of vaccine candidates or potential anti-viral drugs, verify hypotheses based on human studies, gain insights into mechanistic aspects of DENV-induced immunity or pathology, and suggest areas worth attention in future human studies. As with any animal model, extrapolation of findings made in mice to DENV-infection in humans must be done with care. In the future, refinement and improvement of existing models may overcome some of the boundaries of today's models, and expand the knowledge that murine models can generate about mechanisms of DENV pathogenesis and immunity.

\section{REFERENCES}

1. Endy TP, Chunsuttiwat S, Nisalak A, Libraty DH, Green S, Rothman AL, et al. Epidemiology of inapparent and symptomatic acute dengue virus infection: a prospective study of primary school children in Kamphaeng Phet, Thailand. Am J Epidemiol (2002) 156:40-51. doi:10.1093/aje/kwf005

2. World Health Organization. Dengue Guidelines for Diagnosis, Treatment, Prevention and Control: New Edition. Geneva: WHO Press (2009).

3. Carod-Artal FJ, Wichmann O, Farrar J, Gascon J. Neurological complications of dengue virus infection. Lancet Neurol (2013) 12:906-19. doi:10.1016/S14744422(13)70150-9

4. Guzman MG, Alvarez M, Halstead SB. Secondary infection as a risk factor for dengue hemorrhagic fever/dengue shock syndrome: an historical perspective and role of antibody-dependent enhancement of infection. Arch Virol (2013) 158:1445-59. doi:10.1007/s00705-013-1645-3

5. Beatty ME, Stone A, Fitzsimons DW, Hanna JN, Lam SK, Vong S, et al. Best practices in dengue surveillance: a report from the Asia-Pacific and Americas Dengue Prevention Boards. PLoS Negl Trop Dis (2010) 4:e890. doi:10.1371/journal.pntd.0000890

6. Bhatt S, Gething PW, Brady OJ, Messina JP, Farlow AW, Moyes CL, et al. The global distribution and burden of dengue. Nature (2013) 496:504-7. doi: $10.1038 /$ nature 12060

7. Clark KB, Onlamoon N, Hsiao HM, Perng GC, Villinger F. Can non-human primates serve as models for investigating dengue disease pathogenesis? Front Microbiol (2013) 4:305. doi:10.3389/fmicb.2013.00305

8. Halstead SB, Casals J, Shotwell H, Palumbo N. Studies on the immunization of monkeys against dengue. I. Protection derived from single and sequential virus infections. Am J Trop Med Hyg (1973) 22:365-74.

9. Halstead SB, Shotwell H, Casals J. Studies on the pathogenesis of dengue infection in monkeys. I. Clinical laboratory responses to primary infection. J Infect Dis (1973) 128:7-14. doi:10.1093/infdis/128.1.7

10. Halstead SB, Shotwell H, Casals J. Studies on the pathogenesis of dengue infection in monkeys. II. Clinical laboratory responses to heterologous infection. J Infect Dis (1973) 128:15-22. doi:10.1093/infdis/128.1.15

11. Omatsu T, Moi ML, Hirayama T, Takasaki T, Nakamura S, Tajima S, et al. Common marmoset (Callithrix jacchus) as a primate model of dengue virus infection: development of high levels of viraemia and demonstration of protective immunity. J Gen Virol (2011) 92:2272-80. doi:10.1099/vir.0.031229-0

12. Moi ML, Takasaki T, Omatsu T, Nakamura S, Katakai Y, Ami Y, et al. Demonstration of marmosets (Callithrix jacchus) as a non-human primate model for secondary dengue virus infection: high levels of viraemia and serotype crossreactive antibody responses consistent with secondary infection of humans. J Gen Virol (2014) 95:591-600. doi:10.1099/vir.0.060384-0

13. Onlamoon N, Noisakran S, Hsiao HM, Duncan A, Villinger F, Ansari AA, et al. Dengue virus-induced hemorrhage in a nonhuman primate model. Blood (2010) 115:1823-34. doi:10.1182/blood-2009-09-242990

14. Angsubhakorn S, Yoksan S, Bhamarapravati N, Moe JB, Marchette NJ, Pradermwong A, et al. Dengue-4 vaccine: neurovirulence, viraemia and immune responses in rhesus and cynomolgus monkeys. Trans $R$ Soc Trop Med Hyg (1988) 82:746-9. doi:10.1016/0035-9203(88)90224-6
15. Guirakhoo F, Weltzin R, Chambers TJ, Zhang ZX, Soike K, Ratterree M, et al. Recombinant chimeric yellow fever-dengue type 2 virus is immunogenic and protective in nonhuman primates. J Virol (2000) 74:5477-85. doi:10.1128/JVI.74.12.5477-5485.2000

16. Guirakhoo F, Arroyo J, Pugachev KV, Miller C, Zhang ZX, Weltzin R, et al. Construction, safety, and immunogenicity in nonhuman primates of a chimeric yellow fever-dengue virus tetravalent vaccine. J Virol (2001) 75:7290-304. doi:10.1128/JVI.75.16.7290-7304.2001

17. Guirakhoo F, Pugachev K, Zhang Z, Myers G, Levenbook I, Draper K, et al. Safety and efficacy of chimeric yellow Fever-dengue virus tetravalent vaccine formulations in nonhuman primates. J Virol (2004) 78:4761-75. doi:10.1128/JVI.78.9.4761-4775.2004

18. Blaney JE Jr, Matro JM, Murphy BR, Whitehead SS. Recombinant, liveattenuated tetravalent dengue virus vaccine formulations induce a balanced, broad, and protective neutralizing antibody response against each of the four serotypes in rhesus monkeys. J Virol (2005) 79:5516-28. doi:10.1128/JVI.79.9. 5516-5528.2005

19. Raviprakash K, Apt D, Brinkman A, Skinner C, Yang S, Dawes G, et al. A chimeric tetravalent dengue DNA vaccine elicits neutralizing antibody to all four virus serotypes in rhesus macaques. Virology (2006) 353:166-73. doi:10.1016/j.virol.2006.05.005

20. Clements DE, Coller BA, Lieberman MM, Ogata S, Wang G, Harada KE, et al. Development of a recombinant tetravalent dengue virus vaccine: immunogenicity and efficacy studies in mice and monkeys. Vaccine (2010) 28:2705-15. doi:10.1016/j.vaccine.2010.01.022

21. Osorio JE, Brewoo JN, Silengo SJ, Arguello J, Moldovan IR, Tary-Lehmann M, et al. Efficacy of a tetravalent chimeric dengue vaccine (DENVax) in Cynomolgus macaques. Am J Trop Med Hyg (2011) 84:978-87. doi:10.4269/ajtmh.2011. 10-0592

22. White LJ, Sariol CA, Mattocks MD, Wahala WM, Yingsiwaphat V, Collier $\mathrm{ML}$, et al. An alphavirus vector based tetravalent dengue vaccine induces a rapid and protective immune response in macaques that differs qualitatively from immunity induced by live virus infection. J Virol (2013) 87:3409-24. doi:10.1128/JVI.02298-12

23. Zust R, Dong H, Li XF, Chang DC, Zhang B, Balakrishnan T, et al. Rational design of a live attenuated dengue vaccine: $2^{\prime}$-o-methyltransferase mutants are highly attenuated and immunogenic in mice and macaques. PLoS Pathog (2013) 9:e1003521. doi:10.1371/journal.ppat.1003521

24. Huang KJ, Li SY, Chen SC, Liu HS, Lin YS, Yeh TM, et al. Manifestation of thrombocytopenia in dengue-2-virus-infected mice. J Gen Virol (2000) 81:2177-82.

25. Atrasheuskaya A, Petzelbauer P, Fredeking TM, Ignatyev G. Anti-TNF antibody treatment reduces mortality in experimental dengue virus infection. FEMS Immunol Med Microbiol (2003) 35:33-42. doi:10.1111/j.1574-695X. 2003.tb00646.x

26. Shresta S, Kyle JL, Robert Beatty P, Harris E. Early activation of natural killer and $\mathrm{B}$ cells in response to primary dengue virus infection in A/J mice. Virology (2004) 319:262-73. doi:10.1016/j.virol.2003.09.048

27. Paes MV, Pinhao AT, Barreto DF, Costa SM, Oliveira MP, Nogueira AC, et al. Liver injury and viremia in mice infected with dengue-2 virus. Virology (2005) 338:236-46. doi:10.1016/j.virol.2005.04.042

28. Patey O, Ollivaud L, Breuil J, Lafaix C. Unusual neurologic manifestations occurring during dengue fever infection. Am J Trop Med Hyg (1993) 48:793-802.

29. Puccioni-Sohler M, Soares CN, Papaiz-Alvarenga R, Castro MJ, Faria LC, Peralta JM. Neurologic dengue manifestations associated with intrathecal specific immune response. Neurology (2009) 73:1413-7. doi:10.1212/WNL. 0b013e3181bd8258

30. Domingues RB, Kuster GW, Onuki-Castro FL, Souza VA, Levi JE, Pannuti CS. Involvement of the central nervous system in patients with dengue virus infection. J Neurol Sci (2008) 267:36-40. doi:10.1016/j.jns.2007.09.040

31. Araujo F, Nogueira R, Araujo Mde S, Perdigao A, Cavalcanti L, Brilhante R, et al. Dengue in patients with central nervous system manifestations, Brazil. Emerg Infect Dis (2012) 18:677-9. doi:10.3201/eid1804.111552

32. Araujo FM, Araujo MS, Nogueira RM, Brilhante RS, Oliveira DN, Rocha MF, et al. Central nervous system involvement in dengue: a study in fatal cases from a dengue endemic area. Neurology (2012) 78:736-42. doi:10.1212/WNL. 0b013e31824b94e9 
33. Samanta M, Kundu CK, Guha G, Chatterjee S. Unique neurological manifestations of dengue virus in pediatric population: a case series. J Trop Pediatr (2012) 58:398-401. doi:10.1093/tropej/fmr109

34. Bray M, Zhao BT, Markoff L, Eckels KH, Chanock RM, Lai CJ. Mice immunized with recombinant vaccinia virus expressing dengue 4 virus structural proteins with or without nonstructural protein NS1 are protected against fatal dengue virus encephalitis. J Virol (1989) 63:2853-6.

35. Falgout B, Bray M, Schlesinger JJ, Lai CJ. Immunization of mice with recombinant vaccinia virus expressing authentic dengue virus nonstructural protein NS1 protects against lethal dengue virus encephalitis. J Virol (1990) 64:4356-63.

36. Raut CG, Deolankar RP, Kolhapure RM, Goverdhan MK. Susceptibility of laboratory-bred rodents to the experimental infection with dengue virus type 2. Acta Virol (1996) 40:143-6.

37. van Der Most RG, Murali-Krishna K, Ahmed R, Strauss JH. Chimeric yellow fever/dengue virus as a candidate dengue vaccine: quantitation of the dengue virus-specific CD8 T-cell response. J Virol (2000) 74:8094-101. doi:10.1128/ JVI.74.17.8094-8101.2000

38. Chen HC, Hofman FM, Kung JT, Lin YD, Wu-Hsieh BA. Both virus and tumor necrosis factor alpha are critical for endothelium damage in a mouse model of dengue virus-induced hemorrhage. J Virol (2007) 81:5518-26. doi:10.1128/JVI.02575-06

39. Chen HC, Lai SY, Sung JM, Lee SH, Lin YC, Wang WK, et al. Lymphocyte activation and hepatic cellular infiltration in immunocompetent mice infected by dengue virus. J Med Virol (2004) 73:419-31. doi:10.1002/jmv.20108

40. Yamanaka A, Konishi E. A simple method for evaluating dengue vaccine effectiveness in mice based on levels of viremia caused by intraperitoneal injection of infected culture cells. Vaccine (2009) 27:3735-43. doi:10.1016/j.vaccine.2009. 03.083

41. Ashour J, Morrison J, Laurent-Rolle M, Belicha-Villanueva A, Plumlee CR, Bernal-Rubio D, et al. Mouse STAT2 restricts early dengue virus replication. Cell Host Microbe (2010) 8:410-21. doi:10.1016/j.chom.2010.10.007

42. Aguirre S, Maestre AM, Pagni S, Patel JR, Savage T, Gutman D, et al. DENV inhibits type I IFN production in infected cells by cleaving human STING. PLoS Pathog (2012) 8:e1002934. doi:10.1371/journal.ppat.1002934

43. Yu CY, Chang TH, Liang JJ, Chiang RL, Lee YL, Liao CL, et al. Dengue virus targets the adaptor protein MITA to subvert host innate immunity. PLoS Pathog (2012) 8:e1002780. doi:10.1371/journal.ppat.1002780

44. Morrison J, Laurent-Rolle M, Maestre AM, Rajsbaum R, Pisanelli G, Simon $\mathrm{V}$, et al. Dengue virus co-opts UBR4 to degrade STAT2 and antagonize type I interferon signaling. PLoS Pathog (2013) 9:e1003265. doi:10.1371/journal. ppat. 1003265

45. Chen HW, King K, Tu J, Sanchez M, Luster AD, Shresta S. The roles of IRF-3 and IRF-7 in innate antiviral immunity against dengue virus. J Immunol (2013) 191:4194-201. doi:10.4049/jimmunol.1300799

46. Prestwood TR, Morar MM, Zellweger RM, Miller R, May MM, Yauch LE, et al. Gamma interferon (IFN-gamma) receptor restricts systemic dengue virus replication and prevents paralysis in IFN-alpha/beta receptor-deficient mice. J Virol (2012) 86:12561-70. doi:10.1128/JVI.06743-11

47. Johnson AJ, Roehrig JT. New mouse model for dengue virus vaccine testing. J Virol (1999) 73:783-6.

48. Shresta S, Sharar KL, Prigozhin DM, Beatty PR, Harris E. Murine model for dengue virus-induced lethal disease with increased vascular permeability. J Virol (2006) 80:10208-17. doi:10.1128/JVI.00062-06

49. Prestwood TR, Prigozhin DM, Sharar KL, Zellweger RM, Shresta S. A mousepassaged dengue virus strain with reduced affinity for heparan sulfate causes severe disease in mice by establishing increased systemic viral loads. J Virol (2008) 82:8411-21. doi:10.1128/JVI.00611-08

50. Balsitis SJ, Williams KL, Lachica R, Flores D, Kyle JL, Mehlhop E, et al. Lethal antibody enhancement of dengue disease in mice is prevented by Fc modification. PLoS Pathog (2010) 6:e1000790. doi:10.1371/journal.ppat.1000790

51. Zellweger RM, Prestwood TR, Shresta S. Enhanced infection of liver sinusoidal endothelial cells in a mouse model of antibody-induced severe dengue disease. Cell Host Microbe (2010) 7:128-39. doi:10.1016/j.chom.2010.01.004

52. Williams KL, Sukupolvi-Petty S, Beltramello M, Johnson S, Sallusto F, Lanzavecchia A, et al. Therapeutic efficacy of antibodies lacking FcgammaR against lethal dengue virus infection is due to neutralizing potency and blocking of enhancing antibodies. PLoS Pathog (2013) 9:e1003157. doi:10.1371/journal. ppat. 1003157
53. Tan GK, Ng JK, Trasti SL, Schul W, Yip G, Alonso S. A non mouse-adapted dengue virus strain as a new model of severe dengue infection in AG129 mice. PLoS Negl Trop Dis (2010) 4:e672. doi:10.1371/journal.pntd.0000672

54. Grant D, Tan GK, Qing M, Ng JK, Yip A, Zou G, et al. A single amino acid in nonstructural protein NS4B confers virulence to dengue virus in AG129 mice through enhancement of viral RNA synthesis. J Virol (2011) 85:7775-87. doi:10.1128/JVI.00665-11

55. Perry ST, Prestwood TR, Lada SM, Benedict CA, Shresta S. Cardif-mediated signaling controls the initial innate response to dengue virus in vivo. J Virol (2009) 83:8276-81. doi:10.1128/JVI.00365-09

56. Yauch LE, Zellweger RM, Kotturi MF, Qutubuddin A, Sidney J, Peters B, et al. A protective role for dengue virus-specific CD8+ T cells. J Immunol (2009) 182:4865-73. doi:10.4049/jimmunol.0801974

57. Yauch LE, Prestwood TR, May MM, Morar MM, Zellweger RM, Peters B, et al. $\mathrm{CD} 4+\mathrm{T}$ cells are not required for the induction of dengue virus-specific CD8+ $\mathrm{T}$ cell or antibody responses but contribute to protection after vaccination. J Immunol (2010) 185:5405-16. doi:10.4049/jimmunol.1001709

58. Weiskopf D, Yauch LE, Angelo MA, John DV, Greenbaum JA, Sidney J, et al. Insights into HLA-restricted T cell responses in a novel mouse model of dengue virus infection point toward new implications for vaccine design. J Immunol (2011) 187:4268-79. doi:10.4049/jimmunol.1101970

59. Rothman AL. Immunology and immunopathogenesis of dengue disease. $A d v$ Virus Res (2003) 60:397-419. doi:10.1016/S0065-3527(03)60010-2

60. An J, Kimura-Kuroda J, Hirabayashi Y, Yasui K. Development of a novel mouse model for dengue virus infection. Virology (1999) 263:70-7. doi:10.1006/viro. 1999.9887

61. Lin YL, Liao CL, Chen LK, Yeh CT, Liu CI, Ma SH, et al. Study of Dengue virus infection in SCID mice engrafted with human K562 cells. J Virol (1998) 72:9729-37.

62. Bente DA, Melkus MW, Garcia JV, Rico-Hesse R. Dengue fever in humanized NOD/SCID mice. J Virol (2005) 79:13797-9. doi:10.1128/JVI.79.21.1379713799.2005

63. Mota J, Rico-Hesse R. Humanized mice show clinical signs of dengue fever according to infecting virus genotype. J Virol (2009) 83:8638-45. doi:10.1128/ JVI.00581-09

64. Mota J, Rico-Hesse R. Dengue virus tropism in humanized mice recapitulates human dengue fever. PLoS One (2011) 6:e20762. doi:10.1371/journal.pone. 0020762

65. Cox J, Mota J, Sukupolvi-Petty S, Diamond MS, Rico-Hesse R. Mosquito bite delivery of dengue virus enhances immunogenicity and pathogenesis in humanized mice. J Virol (2012) 86:7637-49. doi:10.1128/JVI.00534-12

66. Ishikawa F, Yasukawa M, Lyons B, Yoshida S, Miyamoto T, Yoshimoto $\mathrm{G}$, et al. Development of functional human blood and immune systems in NOD/SCID/IL2 receptor \{gamma\} chain(null) mice. Blood (2005) 106:1565-73. doi:10.1182/blood-2005-02-0516

67. Leung C, Chijioke O, Gujer C, Chatterjee B, Antsiferova O, Landtwing V, et al. Infectious diseases in humanized mice. Eur J Immunol (2013) 43:2246-54. doi:10.1002/eji.201343815

68. Jaiswal S, Pearson T, Friberg H, Shultz LD, Greiner DL, Rothman AL, et al. Dengue virus infection and virus-specific HLA-A2 restricted immune responses in humanized NOD-scid IL2rgammanull mice. PLoS One (2009) 4:e7251. doi:10.1371/journal.pone.0007251

69. Kuruvilla JG, Troyer RM, Devi S, Akkina R. Dengue virus infection and immune response in humanized RAG2(-/-)gamma(c) (-/-) (RAG-hu) mice. Virology (2007) 369:143-52. doi:10.1016/j.virol.2007.06.005

70. Jaiswal S, Pazoles P, Woda M, Shultz LD, Greiner DL, Brehm MA, et al. Enhanced humoral and HLA-A2-restricted dengue virus-specific T-cell responses in humanized BLT NSG mice. Immunology (2012) 136:334-43. doi:10.1111/j.1365-2567.2012.03585.x

71. Frias-Staheli N, Dorner M, Marukian S, Billerbeck E, Labitt RN, Rice CM, et al. Utility of humanized BLT mice for analysis of dengue virus infection and antiviral drug testing. J Virol (2014) 88:2205-18. doi:10.1128/JVI.03085-13

72. Courageot MP, Frenkiel MP, Dos Santos CD, Deubel V, Despres P. Alphaglucosidase inhibitors reduce dengue virus production by affecting the initial steps of virion morphogenesis in the endoplasmic reticulum. J Virol (2000) 74:564-72. doi:10.1128/JVI.74.1.564-572.2000

73. Whitby K, Pierson TC, Geiss B, Lane K, Engle M, Zhou Y, et al. Castanospermine, a potent inhibitor of dengue virus infection in vitro and in vivo. J Virol (2005) 79:8698-706. doi:10.1128/JVI.79.14.8698-8706.2005 
74. Wu SF, Lee CJ, Liao CL, Dwek RA, Zitzmann N, Lin YL. Antiviral effects of an iminosugar derivative on flavivirus infections. J Virol (2002) 76:3596-604. doi:10.1128/JVI.76.8.3596-3604.2002

75. Schul W, Liu W, Xu HY, Flamand M, Vasudevan SG. A dengue fever viremia model in mice shows reduction in viral replication and suppression of the inflammatory response after treatment with antiviral drugs. J Infect Dis (2007) 195:665-74. doi:10.1086/511310

76. Chang J, Schul W, Butters TD, Yip A, Liu B, Goh A, et al. Combination of alphaglucosidase inhibitor and ribavirin for the treatment of dengue virus infection in vitro and in vivo. Antiviral Res (2011) 89:26-34. doi:10.1016/j.antiviral.2010. 11.002

77. Chang J, Schul W, Yip A, Xu X, Guo JT, Block TM. Competitive inhibitor of cellular alpha-glucosidases protects mice from lethal dengue virus infection. Antiviral Res (2011) 92:369-71. doi:10.1016/j.antiviral.2011.08.003

78. Rathore AP, Paradkar PN, Watanabe S, Tan KH, Sung C, Connolly JE, et al. Celgosivir treatment misfolds dengue virus NS1 protein, induces cellular prosurvival genes and protects against lethal challenge mouse model. Antiviral Res (2011) 92:453-60. doi:10.1016/j.antiviral.2011.10.002

79. Miller JL, Lachica R, Sayce AC, Williams JP, Bapat M, Dwek R, et al. Liposomemediated delivery of iminosugars enhances efficacy against dengue virus in vivo. Antimicrob Agents Chemother (2012) 56:6379-86. doi:10.1128/AAC. 01554- 12

80. Perry ST, Buck MD, Plummer EM, Penmasta RA, Batra H, Stavale EJ, et al. An iminosugar with potent inhibition of dengue virus infection in vivo. Antiviral Res (2013) 98:35-43. doi:10.1016/j.antiviral.2013.01.004

81. Chen YL, Yin Z, Duraiswamy J, Schul W, Lim CC, Liu B, et al. Inhibition of dengue virus RNA synthesis by an adenosine nucleoside. Antimicrob Agents Chemother (2010) 54:2932-9. doi:10.1128/AAC.00140-10

82. Chen YL, Yin Z, Lakshminarayana SB, Qing M, Schul W, Duraiswamy J, et al. Inhibition of dengue virus by an ester prodrug of an adenosine analog. Antimicrob Agents Chemother (2010) 54:3255-61. doi:10.1128/AAC.00397-10

83. Wang QY, Kondreddi RR, Xie X, Rao R, Nilar S, Xu HY, et al. A translation inhibitor that suppresses dengue virus in vitro and in vivo. Antimicrob Agents Chemother (2011) 55:4072-80. doi:10.1128/AAC.00620-11

84. Byrd CM, Grosenbach DW, Berhanu A, Dai D, Jones KF, Cardwell KB, et al. Novel benzoxazole inhibitor of dengue virus replication that targets the NS3 helicase. Antimicrob Agents Chemother (2013) 57:1902-12. doi:10.1128/AAC. 02251- 12

85. Byrd CM, Dai D, Grosenbach DW, Berhanu A, Jones KF, Cardwell KB, et al. A novel inhibitor of dengue virus replication that targets the capsid protein. Antimicrob Agents Chemother (2013) 57:15-25. doi:10.1128/AAC.01429-12

86. Blaney JE Jr, Johnson DH, Firestone CY, Hanson CT, Murphy BR, Whitehead SS. Chemical mutagenesis of dengue virus type 4 yields mutant viruses which are temperature sensitive in vero cells or human liver cells and attenuated in mice. J Virol (2001) 75:9731-40. doi:10.1128/JVI.75.20.9731-9740.2001

87. Blaney JE Jr, Johnson DH, Manipon GG, Firestone CY, Hanson CT, Murphy BR, et al. Genetic basis of attenuation of dengue virus type 4 small plaque mutants with restricted replication in suckling mice and in SCID mice transplanted with human liver cells. Virology (2002) 300:125-39. doi:10.1006/viro.2002.1528

88. Blaney JE Jr, Hanson CT, Firestone CY, Hanley KA, Murphy BR, Whitehead SS. Genetically modified, live attenuated dengue virus type 3 vaccine candidates. Am J Trop Med Hyg (2004) 71:811-21.

89. World Health Organization. WHO Expert Committee on Biological Standardization. World Health Organization Technical Report Series (2013) 1-366.

90. Zellweger RM, Miller R, Eddy WE, White LJ, Johnston RE, Shresta S. Role of humoral versus cellular responses induced by a protective dengue vaccine candidate. PLoS Pathog (2013) 9(10):e1003723. doi:10.1371/journal.ppat.1003723

91. Huang CY, Butrapet S, Tsuchiya KR, Bhamarapravati N, Gubler DJ, Kinney RM. Dengue 2 PDK-53 virus as a chimeric carrier for tetravalent dengue vaccine development. J Virol (2003) 77:11436-47. doi:10.1128/JVI.77.21.1143611447.2003

92. Brewoo JN, Kinney RM, Powell TD, Arguello JJ, Silengo SJ, Partidos CD, et al. Immunogenicity and efficacy of chimeric dengue vaccine (DENVax) formulations in interferon-deficient AG129 mice. Vaccine (2012) 30:1513-20. doi:10.1016/j.vaccine.2011.11.072

93. Etemad B, Batra G, Raut R, Dahiya S, Khanam S, Swaminathan S, et al. An envelope domain III-based chimeric antigen produced in Pichia pastoris elicits neutralizing antibodies against all four dengue virus serotypes. Am J Trop Med Hyg (2008) 79:353-63.
94. Leng CH, Liu SJ, Tsai JP, Li YS, Chen MY, Liu HH, et al. A novel dengue vaccine candidate that induces cross-neutralizing antibodies and memory immunity. Microbes Infect (2009) 11:288-95. doi:10.1016/j.micinf.2008.12.004

95. Mellado-Sanchez G, Garcia-Cordero J, Luria-Perez R, Lazaro-Olan L, SantosArgumedo L, Gutierrez-Castaneda B, et al. DNA priming E and NS1 constructs - homologous proteins boosting immunization strategy to improve immune response against dengue in mice. Viral Immunol (2005) 18:709-21. doi:10.1089/vim.2005.18.709

96. Mellado-Sanchez G, Garcia-Machorro J, Sandoval-Montes C, GutierrezCastaneda B, Rojo-Dominguez A, Garcia-Cordero J, et al. A plasmid encoding parts of the dengue virus $\mathrm{E}$ and NS1 proteins induces an immune response in a mouse model. Arch Virol (2010) 155:847-56. doi:10.1007/s00705-010-0652-x

97. Chen S, Yu M, Jiang T, Deng Y, Qin C, Qin E. Induction of tetravalent protective immunity against four dengue serotypes by the tandem domain III of the envelope protein. DNA Cell Biol (2007) 26:361-7. doi:10.1089/dna.2006.0547

98. White LJ, Parsons MM, Whitmore AC, Williams BM, De Silva A, Johnston RE. An immunogenic and protective alphavirus replicon particle-based dengue vaccine overcomes maternal antibody interference in weanling mice. J Virol (2007) 81:10329-39. doi:10.1128/JVI.00512-07

99. Zheng Q, Fan D, Gao N, Chen H, Wang J, Ming Y, et al. Evaluation of a DNA vaccine candidate expressing prM-E-NS1 antigens of dengue virus serotype 1 with or without granulocyte-macrophage colony-stimulating factor (GM-CSF) in immunogenicity and protection. Vaccine (2011) 29:763-71. doi:10.1016/j.vaccine.2010.11.014

100. Halstead SB, Nimmannitya S, Cohen SN. Observations related to pathogenesis of dengue hemorrhagic fever. IV. Relation of disease severity to antibody response and virus recovered. Yale J Biol Med (1970) 42:311-28.

101. Halstead SB. Neutralization and antibody-dependent enhancement of dengue viruses. Adv Virus Res (2003) 60:421-67. doi:10.1016/S0065-3527(03)60011-4

102. Kliks SC, Nisalak A, Brandt WE, Wahl L, Burke DS. Antibody-dependent enhancement of dengue virus growth in human monocytes as a risk factor for dengue hemorrhagic fever. Am J Trop Med Hyg (1989) 40:444-51.

103. Mehlhop E, Ansarah-Sobrinho C, Johnson S, Engle M, Fremont DH, Pierson TC, et al. Complement protein C1q inhibits antibody-dependent enhancement of flavivirus infection in an IgG subclass-specific manner. Cell Host Microbe (2007) 2:417-26. doi:10.1016/j.chom.2007.09.015

104. Pierson TC, Xu Q, Nelson S, Oliphant T, Nybakken GE, Fremont DH, et al. The stoichiometry of antibody-mediated neutralization and enhancement of West Nile virus infection. Cell Host Microbe (2007) 1:135-45. doi:10.1016/j.chom. 2007.03.002

105. Boonnak K, Slike BM, Burgess TH, Mason RM, Wu SJ, Sun P, et al. Role of dendritic cells in antibody-dependent enhancement of dengue virus infection. J Virol (2008) 82:3939-51. doi:10.1128/JVI.02484-07

106. Kou Z, Quinn M, Chen H, Rodrigo WW, Rose RC, Schlesinger JJ, et al. Monocytes, but not $\mathrm{T}$ or $\mathrm{B}$ cells, are the principal target cells for dengue virus (DV) infection among human peripheral blood mononuclear cells. J Med Virol (2008) 80:134-46. doi:10.1002/jmv.21051

107. Halstead SB. In vivo enhancement of dengue virus infection in rhesus monkeys by passively transferred antibody. J Infect Dis (1979) 140:527-33. doi:10.1093/infdis/140.4.527

108. Goncalvez AP, Engle RE, St Claire M, Purcell RH, Lai CJ. Monoclonal antibodymediated enhancement of dengue virus infection in vitro and in vivo and strategies for prevention. Proc Natl Acad Sci U S A (2007) 104:9422-7. doi:10.1073/pnas.0703498104

109. Murgue B, Roche C, Chungue E, Deparis X. Prospective study of the duration and magnitude of viraemia in children hospitalised during the 19961997 dengue-2 outbreak in French Polynesia. J Med Virol (2000) 60:432-8. doi:10.1002/(SICI) 1096-9071(200004)60:4<432::AID-JMV11>3.0.CO;2-7

110. Vaughn DW, Green S, Kalayanarooj S, Innis BL, Nimmannitya S, Suntayakorn $S$, et al. Dengue viremia titer, antibody response pattern, and virus serotype correlate with disease severity. J Infect Dis (2000) 181:2-9. doi:10.1086/315215

111. Libraty DH, Endy TP, Houng HS, Green S, Kalayanarooj S, Suntayakorn S, et al. Differing influences of virus burden and immune activation on disease severity in secondary dengue-3 virus infections. J Infect Dis (2002) 185:1213-21. doi:10.1086/340365

112. Wang WK, Chao DY, Kao CL, Wu HC, Liu YC, Li CM, et al. High levels of plasma dengue viral load during defervescence in patients with dengue hemorrhagic fever: implications for pathogenesis. Virology (2003) 305:330-8. doi:10.1006/viro.2002.1704 
113. Nguyet MN, Duong TH, Trung VT, Nguyen TH, Tran CN, Long VT, et al. Host and viral features of human dengue cases shape the population of infected and infectious Aedes aegypti mosquitoes. Proc Natl Acad Sci U S A (2013) 110:9072-7. doi:10.1073/pnas.1303395110

114. Perry ST, Buck MD, Lada SM, Schindler C, Shresta S. STAT2 mediates innate immunity to Dengue virus in the absence of STAT1 via the type I interferon receptor. PLoS Pathog (2011) 7:e1001297. doi:10.1371/journal.ppat.1001297

115. Kliks SC, Nimmanitya S, Nisalak A, Burke DS. Evidence that maternal dengue antibodies are important in the development of dengue hemorrhagic fever in infants. Am J Trop Med Hyg (1988) 38:411-9.

116. Halstead SB, Lan NT, Myint TT, Shwe TN, Nisalak A, Kalyanarooj S, et al. Dengue hemorrhagic fever in infants: research opportunities ignored. Emerg Infect Dis (2002) 8:1474-9. doi:10.3201/eid0812.020170

117. Pengsaa K, Luxemburger C, Sabchareon A, Limkittikul K, Yoksan S, Chambonneau L, et al. Dengue virus infections in the first 2 years of life and the kinetics of transplacentally transferred dengue neutralizing antibodies in Thai children. J Infect Dis (2006) 194:1570-6. doi:10.1086/508492

118. Chau TN, Hieu NT, Anders KL, Wolbers M, Lien Le B, Hieu LT, et al. Dengue virus infections and maternal antibody decay in a prospective birth cohort study of Vietnamese infants. J Infect Dis (2009) 200:1893-900. doi:10.1086/ 648407

119. Mongkolsapaya J, Dejnirattisai W, Xu XN, Vasanawathana S, Tangthawornchaikul N, Chairunsri A, et al. Original antigenic sin and apoptosis in the pathogenesis of dengue hemorrhagic fever. Nat Med (2003) 9:921-7. doi:10. $1038 / \mathrm{nm} 887$

120. Mangada MM, Rothman AL. Altered cytokine responses of dengue-specific CD4+ T cells to heterologous serotypes. J Immunol (2005) 175:2676-83.

121. Dong T, Moran E, Vinh Chau N, Simmons C, Luhn K, Peng Y, et al. High pro-inflammatory cytokine secretion and loss of high avidity cross-reactive cytotoxic T-cells during the course of secondary dengue virus infection. PLoS One (2007) 2:e1192. doi:10.1371/journal.pone.0001192

122. Weiskopf D, Angelo MA, De Azeredo EL, Sidney J, Greenbaum JA, Fernando AN, et al. Comprehensive analysis of dengue virus-specific responses supports an HLA-linked protective role for CD8+ T cells. Proc Natl Acad Sci U S A (2013) 110:E2046-53. doi:10.1073/pnas.1305227110

123. Kaufman BM, Summers PL, Dubois DR, Eckels KH. Monoclonal antibodies against dengue 2 virus E-glycoprotein protect mice against lethal dengue infection. Am J Trop Med Hyg (1987) 36:427-34.

124. Kyle JL, Balsitis SJ, Zhang L, Beatty PR, Harris E. Antibodies play a greater role than immune cells in heterologous protection against secondary dengue virus infection in a mouse model. Virology (2008) 380:296-303. doi:10.1016/j.virol. 2008.08.008

125. Zompi S, Santich BH, Beatty PR, Harris E. Protection from secondary dengue virus infection in a mouse model reveals the role of serotype cross-reactive $\mathrm{B}$ and T cells. J Immunol (2012) 188:404-16. doi:10.4049/jimmunol.1102124

126. Durbin AP, Whitehead SS. Next-generation dengue vaccines: novel strategies currently under development. Viruses (2011) 3:1800-14. doi:10.3390/ v3101800

127. Guy B, Barrere B, Malinowski C, Saville M, Teyssou R, Lang J. From research to phase III: preclinical, industrial and clinical development of the Sanofi Pasteur tetravalent dengue vaccine. Vaccine (2011) 29:7229-41. doi:10.1016/j.vaccine. 2011.06.094

128. Schmitz J, Roehrig J, Barrett A, Hombach J. Next generation dengue vaccines: a review of candidates in preclinical development. Vaccine (2011) 29:7276-84. doi:10.1016/j.vaccine.2011.07.017

129. Thomas SJ, Endy TP. Vaccines for the prevention of dengue: development update. Hum Vaccin (2011) 7:674-84. doi:10.4161/hv.7.6.14985

130. Defeating dengue: a challenge for a vaccine. Nat Med (2012) 18:1622-3. doi: $10.1038 / \mathrm{nm} .2997$
131. Halstead SB. Dengue vaccine development: a $75 \%$ solution? Lancet (2012) 380:1535-6. doi:10.1016/S0140-6736(12)61510-4

132. Halstead SB. Identifying protective dengue vaccines: guide to mastering an empirical process. Vaccine (2013) 31:4501-7. doi:10.1016/j.vaccine.2013.06. 079

133. Fink K, Shi PY. Live attenuated vaccine: the first clinically approved dengue vaccine? Expert Rev Vaccines (2014) 13:185-8. doi:10.1586/14760584.2014.870888

134. Xu M, Hadinoto V, Appanna R, Joensson K, Toh YX, Balakrishnan T, et al. Plasmablasts generated during repeated dengue infection are virus glycoproteinspecific and bind to multiple virus serotypes. J Immunol (2012) 189:5877-85. doi:10.4049/jimmunol.1201688

135. Durbin AP, Whitehead SS. The dengue human challenge model: has the time come to accept this challenge? J Infect Dis (2013) 207:697-9. doi:10.1093/infdis/ jis749

136. Wahid SF, Sanusi S, Zawawi MM, Ali RA. A comparison of the pattern of liver involvement in dengue hemorrhagic fever with classic dengue fever. Southeast Asian J Trop Med Public Health (2000) 31:259-63.

137. Syhavong B, Rasachack B, Smythe L, Rolain JM, Roque-Afonso AM, Jenjaroen $\mathrm{K}$, et al. The infective causes of hepatitis and jaundice amongst hospitalised patients in Vientiane, Laos. Trans R Soc Trop Med Hyg (2010) 104:475-83. doi:10.1016/j.trstmh.2010.03.002

138. Pagliari C, Quaresma JA, Fernandes ER, Stegun FW, Brasil RA, De Andrade HF $\mathrm{Jr}$, et al. Immunopathogenesis of dengue hemorrhagic fever: contribution to the study of human liver lesions. J Med Virol (2013). doi:10.1002/jmv.23758

139. Roy A, Sarkar D, Chakraborty S, Chaudhuri J, Ghosh P, Chakraborty S. Profile of hepatic involvement by dengue virus in dengue infected children. $N$ Am J Med Sci (2013) 5:480-5. doi:10.4103/1947-2714.117313

140. Umar S, Ahmad B, Rana MY, Khan Khattak JZ, Shabbir MI. Hepatic dysfunction in patients infected with dengue virus. J Coll Physicians Surg Pak (2014) 24:74

141. Rosen L, Drouet MT, Deubel V. Detection of dengue virus RNA by reverse transcription-polymerase chain reaction in the liver and lymphoid organs but not in the brain in fatal human infection. Am J Trop Med Hyg (1999) 61:720-4.

142. Jessie K, Fong MY, Devi S, Lam SK, Wong KT. Localization of dengue virus in naturally infected human tissues, by immunohistochemistry and in situ hybridization. J Infect Dis (2004) 189:1411-8. doi:10.1086/383043

143. Balsitis SJ, Coloma J, Castro G, Alava A, Flores D, Mckerrow JH, et al. Tropism of dengue virus in mice and humans defined by viral nonstructural protein 3-specific immunostaining. Am J Trop Med Hyg (2009) 80:416-24.

144. Saigal S, Choudhary NS, Saraf N, Kataria S, Mohanka R, Soin AS. Transmission of dengue virus from a donor to a recipient after living donor liver transplantation. Liver Transpl (2013) 19:1413-4. doi:10.1002/lt.23755

Conflict of Interest Statement: The authors declare that the research was conducted in the absence of any commercial or financial relationships that could be construed as a potential conflict of interest.

Received: 31 January 2014; accepted: 21 March 2014; published online: 10 April 2014. Citation: Zellweger RM and Shresta S (2014) Mouse models to study dengue virus immunology and pathogenesis. Front. Immunol. 5:151. doi: 10.3389/fimmu.2014.00151

This article was submitted to Microbial Immunology, a section of the journal Frontiers in Immunology.

Copyright (c) 2014 Zellweger and Shresta. This is an open-access article distributed under the terms of the Creative Commons Attribution License (CC BY). The use, distribution or reproduction in other forums is permitted, provided the original author(s) or licensor are credited and that the original publication in this journal is cited, in accordance with accepted academic practice. No use, distribution or reproduction is permitted which does not comply with these terms. 